\title{
Evaluation and Comparison of Serological Methods for COVID-19 Diagnosis
}

\author{
Fanwu Gong ${ }^{1}$, Hua-xing Wei ${ }^{2}$, Qiangsheng $L i^{1}$, Liu $L i u^{3 *}$ and Bofeng $L i^{1 *}$ \\ ${ }^{1}$ Department of Medical Oncology, The First Affiliated Hospital of USTC, Division of Life Sciences and Medicine, University of \\ Science and Technology of China, Hefei, China, ${ }^{2}$ Department of Laboratory Medicine, The First Affiliated Hospital of USTC, \\ Division of Life Sciences and Medicine, University of Science and Technology of China, Hefei, China, ${ }^{3}$ Department of General \\ Surgery, The First Affiliated Hospital of USTC, University of Science and Technology of China, Hefei, China
}

OPEN ACCESS

Edited by:

Yan Xiang,

The University of Texas Health Science Center at San Antonio, United States

Reviewed by:

Doyoun Kim,

Korea Research Institute of Chemical Technology (KRICT), South Korea Massimo Pieri, University of Rome Tor Vergata, Italy

Tiancai Liu,

Southern Medical University, China

*Correspondence:

Liu Liu

Liuwkjy@126.com

Bofeng Li

libf@ustc.edu.cn

Specialty section:

This article was submitted to

Structural Biology,

a section of the journal

Frontiers in Molecular Biosciences

Received: 18 March 2021 Accepted: 30 June 2021

Published: 23 July 2021

Citation:

Gong F, Wei H, Li Q, Liu L and Li B (2021) Evaluation and Comparison of

Serological Methods for COVID-

19 Diagnosis.

Front. Mol. Biosci. 8:682405.

doi: 10.3389/fmolb.2021.682405
The worldwide pandemic of COVID-19 has become a global public health crisis. Various clinical diagnosis methods have been developed to distinguish COVID-19-infected patients from healthy people. The nucleic acid test is the golden standard for virus detection as it is suitable for early diagnosis. However, due to the low amount of viral nucleic acid in the respiratory tract, the sensitivity of nucleic acid detection is unsatisfactory. As a result, serological screening began to be widely used with the merits of simple procedures, lower cost, and shorter detection time. Serological tests currently include the enzyme-linked immunosorbent assay (ELISA), lateral flow immunoassay (LFIA), and chemiluminescence immunoassay (CLIA). This review describes various serological methods, discusses the performance and diagnostic effects of different methods, and points out the problems and the direction of optimization, to improve the efficiency of clinical diagnosis. These increasingly sophisticated and diverse serological diagnostic technologies will help human beings to control the spread of COVID-19.

Keywords: COVID-19 diagnosis, serological testing, antibody, SARS-CoV-2, ELISA, LFIA

\section{INTRODUCTION}

The global public health and economy have steadily deteriorated by the spread of SARS-CoV-2 (severe acute respiratory syndrome coronavirus 2) (Asselah et al., 2021). Up to now, SARS-CoV-2 has infected more than 119 million people, resulting in more than 2,600,000 deaths. On December 8, 2019 , the first SARS-CoV-2 infection case was reported in Wuhan, China. The Chinese government announced the existence of the novel coronavirus and took effective measures to control the spread of the virus (The Lancet 2020; Zhang et al., 2020). Unfortunately, the virus spread rapidly and widely all over the world (Krouse, 2020; Krishnan et al., 2021). Interestingly, a recent study reported 106 out of 7,389 blood samples, with an earliest donation on December 13, 2019, were identified as SARSCoV-2 positive (Basavaraju et al., 2020). It takes more than one week for humans to produce IgG after infection (Long et al., 2020; Xiang et al., 2020), indicating SARS-COV-2 might have already spread in the world earlier than it appeared in China.

The common symptoms of COVID-19 patients include fever, cough, breathlessness, and dyspnea. In more severe cases, SARS-COV-2 infection can lead to pneumonia, kidney failure, and even death (Berlin et al., 2020; Gandhi et al., 2020). The coronavirus family contains four genera: $\alpha \mathrm{CoV}, \beta \mathrm{CoV}$, $\gamma \mathrm{CoV}$, and $\delta \mathrm{CoV}$. Mammalian coronaviruses are mainly a $\mathrm{CoV}$ and $\beta \mathrm{CoV}$, which can infect a variety of animals including pigs, dogs, cats, mice, cattle, and horses. Avian coronavirus is mainly derived 
from $\gamma$ and $\delta$ coronaviruses, causing a variety of birds to get the disease. Currently, seven members of the coronavirus family are pathogenic to human beings (Woo et al., 2009). In addition to the three high pathogenic coronaviruses (SARS-CoV, MERS-CoV, and SARS-CoV-2), the other four human coronaviruses (HCoV229E, HCoV-OC43, HCoV-NL63, and HCoV-HKU1) usually cause mild-to-moderate upper respiratory diseases in people (Fung and Liu, 2019). Several structural proteins are anchored on the membrane surface of coronavirus, mainly spike (S), nucleocapsid $(\mathrm{N})$, membrane $(\mathrm{M})$, and envelope (E) proteins (Malik, 2020). S protein is a key antigen out of the virus membrane that stimulates the host to produce a significant number of neutralizing antibodies (NAbs). The $S$ protein contains S1 and S2 subunits and forms a large trimer $(20 \mathrm{~nm}$ in length), the receptor binding domain (RBD) on the $\mathrm{S} 1$ subunit can bind to human ACE2 protein on the surface of epithelial cells, while S2 mediates the subsequent membrane fusion that allows the virus to enter the host cytoplasm. M glycoprotein is the most abundant component in coronaviruses. To shape the membranous virions and integrate necessary components into nascent virions, the binding of N protein with viral RNA can form spiral $\mathrm{N}$ protein, which is mainly responsible for wrapping and assembling viral genomes, maintaining the stability of the viral structure. E protein participates in viral assembly by forming ion channels on the viral cell membrane (Weiss and Leibowitz, 2011; Malik, 2020).

\section{PRINCIPLES OF SEROLOGICAL DETECTION: OVERVIEW}

When a virus invades the human body and releases virus antigens into the bloodstream, the human immune system is then triggered to continuously produce a large number of specific antibodies (IgM/IgA/IgG) that are more concentrated than the antigenic protein and last for a long time (Reading and Dimmock, 2007; Combadiere, 2020; Yu et al., 2020). Therefore, compared to viral antigens, researchers prefer to use serological antibodies as diagnostic targets to develop faster, easier, and more sensitive serological tests (Espejo et al., 2020). Based on the immunology principle, detecting virus-specific antibodies showed more accurate results than detecting total immunoglobulin (Ig). Therefore, various studies have selected $\mathrm{S}$ or $\mathrm{N}$ protein-specific antibodies (IgM/IgA/IgG) as SARS-CoV-2 diagnosis targets ( $\mathrm{Li}$ and Li, 2020; Mekonnen et al., 2020). Furthermore, some researchers even chose the S1 subunit or the RBD (receptor binding domain) as an antigen to improve the specificity of detection (Chen et al., 2020; Khan et al., 2020; Okba et al., 2020). For these different types of antibodies, IgM and IgA are produced by host immune cells at an early stage of infection while IgG at the late stage (Woo et al., 2004; Lam et al., 2020; Ma et al., 2020). Vashist et al. reported that IgA was positive in the serum $5^{\circ}$ days after infection while IgM after 10-30 days and IgG after 20-90 days (Vashist, 2020). Therefore, the effectiveness of the COVID-19 serological test at an early stage of viral infection is not satisfied. A study has shown that only $50 \%$ of patients with SARS-CoV-2 infection had IgM and IgG positive in their serum one week after the onset of symptoms (Wolfel et al., 2020). However, the serum antibody concentrations would increase significantly over time, while the viral load would gradually decrease (Guo et al., 2020; Xiang et al., 2020). This means that serological detection is more effective than RT-PCR at the middle-late stage of infection. Moreover, serological detection results can reflect the severity of the patient's symptoms, while RT-PCR results can hardly do. Yu et al. showed that IgM and IgG levels were significantly higher in severe COVID-19 patients than in mild-to-moderate patients (Yu et al., 2020). Currently, most serological test kits use specific IgM and IgG as detection targets (Ward et al., 2020). As IgA concentrations are higher than those of IgM and IgG in the early stages of infection (Vashist, 2020), some studies have proposed detection methods for IgA. Moreover, it is believed that the combined detection of multiple antibodies is helpful to improve the diagnostic accuracy of COVID-19 (Ma et al., 2020; Su et al., 2020).

\section{SEROLOGICAL TESTS FOR THE COVID-19 DIAGNOSIS}

As mentioned above, most serological detection methods rely on the principle of antigen-antibody-specific binding by detecting antibody levels in the human serum. The main serological detection methods include the chemiluminescence immunoassay (CLIA), enzyme-linked immunosorbent assay (ELISA), lateral flow immunoassay (LFIA), and immunofluorescence assay (IFA) (Ejazi et al., 2021; Mekonnen et al., 2020). These methods all have their own advantages and disadvantages, based on detection efficiency, system cost, the convenience of operation, and diagnosis restrictions (Kubina and Dziedzic, 2020), which will be fully discussed in this review.

\section{Enzyme-Linked Immunosorbent Assay}

ELISA is the most commonly used classical serological test, with an average detection time between 2 and $8 \mathrm{~h}$ (Mekonnen et al., 2020). It was invented in the 1960s and is widely used from the 1970s till now (Lequin, 2005). According to the properties of detected target proteins and detection strategies, the ELISA can be divided into the sandwich ELISA, indirect ELISA, double antibody ELISA, competitive ELISA, blocking ELISA, and other different types (Butler, 2000). The indirect ELISA method is most commonly used in COVID-19 serological diagnosis (Mekonnen et al., 2020). The basic process of this method is to coat virus protein $(\mathrm{N}, \mathrm{S}), \mathrm{S}$ protein subunit $(\mathrm{S} 1)$, or protein domain (RBD) on the solid phase carrier that binds with serum antibody and enzyme-linked antibodies to produce a chromogenic reaction (Lin, 2015). In addition to serum testing, Varadhachary et al. have developed a small automated ELISA device for detecting SARS-CoV-2-specific IgA levels in human saliva that can be used for the standard ELISA in less than 15 min (Varadhachary et al., 2020). Waleed established an ELISA test to detect antibodies against the SARS-CoV-2 S protein and S1/S2 subunit in the serum and compared their performance. They found the full-length $S$ protein showed the strongest reactivity to IgG, while $S 1$ showed the highest specificity 
(Mahallawi, 2021). Isho et al. designed an ELISA test to detect S protein-specific and RBD-specific IgG/IgA/IgM in patients' serum (Isho et al., 2020). At present, there are many commercial SARS-CoV-2 detection kits by targeting different types of antigens and antibodies on the market (Lassaunière et al., 2020; Whitman et al., 2020), and the effectiveness of these kits will be evaluated in this review. Because the operation process of ELISA is comparably complicated (Sidiq et al., 2020), some manufacturers completed the encapsulated and closed steps beforehand and tried to merge the subsequent detection steps to shorten the procedure time (Manalac et al., 2020).

\section{Chemiluminescence Immunoassay}

The principle of the CLIA is similar to that of the ELISA taking advantage of the high binding affinity between viral antigens and host antibodies, but the difference is the CLIA uses a chemical reaction to produce a glowing chemical probe to detect a positive signal (Weeks et al., 1986; Lin et al., 2019). Typically, CLIA results are obtained in 0.5-2 h (Vashist, 2020; Weeks et al., 1986). Like the ELISA, the CLIA is a high-throughput assay with higher accuracy and a low signal-to-noise ratio (Padoan et al., 2020; Tan et al., 2020). Taking S protein-specific IgG, for example, S-conjugated magnetic beads are co-incubated with serum samples and anti-human enzyme-linked antibodies to produce chemiluminescence. Currently, the detection steps after the magnetic bead-conjugated antigen are usually performed by the chemical immuno-luminescence analyzer, which greatly shortens detection time but increases the reliance on large detection instruments (Cai et al., 2020; Lin et al., 2020). Cai et al. used the combined detection of IgM and IgG antibodies and improved the performance of CLIA detection compared to the single antibody detection. They observed a positive rate of $81.52 \%$ for IgM and IgG tests, higher than that of the IgG test (57.2\%) or IgM test (71.4\%) alone (Cai et al., 2020). They used a magnetic chemiluminescent enzyme immunoassay (MCLIA) to detect antibodies against the $\mathrm{N}$ and $\mathrm{S}$ antigens of SARS-CoV-2 (Cai et al., 2020). Similarly, Ma et al. used the CLIA method to detect RBD-specific IgA, IgM, and IgG in the blood of patients with SARS-CoV-2 infection, with a sensitivity of $98.6,96.8$, and $96.8 \%$, respectively, and a specificity of 98.1, 92.3, and $99.8 \%$, respectively. On combined detection of the three antibodies, the sensitivity and specificity increased to 99.5 and $100 \%$, respectively (Ma et al., 2020). Currently, the accuracy of CLIA test results is often higher than that of other methods' results.

\section{Lateral Flow Immunoassay}

Lateral flow immunoassay (LFIA) is a low-cost, simple, fast, and portable test. It is widely used in biomedical, agricultural, food, and environmental sciences. For example, pregnancy test kits in the health field are successful applications of this technology (Koczula and Gallotta, 2016). In 1988, the Unilever subsidiary invented the first commercial home pregnancy test based on a transverse flow test (Ernst et al., 2021). Actually, the LFIA is a paper-based detection and analysis platform. This instant diagnostic method only needs $3-30 \mathrm{~min}$ to complete all processes as well as a small amount of sample load (Carrio et al., 2015; Moreno et al., 2017). A variety of biological samples can be used for LFIA detection, including serum, plasma, whole blood, urine, saliva, tears, and other liquids (Magambo et al., 2014; Schramm et al., 2015; Ang et al., 2016). As shown in Figure 1, typical LFIA equipment usually consists of five elements: sample pad, conjugate release pad, membrane with immobilized antibodies, adsorbent pad, and adhesive pad (Koczula and Gallotta, 2016; Montesinos et al., 2020). By siphoning a liquid sample, fixed antibodies on the dipstick can interact with the target molecule (Anfossi et al., 2018; Bever et al., 2020). Most LFIA tests for COVID-19 diagnosis use colloidal gold labeled with SARS-CoV-2 antigen. After identifying the corresponding antibody, the SARS-CoV-2 antibody can capture virus antigen from serum or whole blood (Machado et al., 2020; Goudouris, 2021). Therefore, the LFIA has the potential to be used for large-scale serological and instantaneous COVID-19 diagnosis. The process of LFIA for COVID-19 antibody diagnosis is definitely simple. Taking S protein-specific IgG, for example, a drop of whole blood is added to the sample pad and then made to flow through a conjugate release pad containing $S$ protein-specific IgG and control IgG (such as rabbit IgG) conjugated with colored or fluorescent particles. Accompanied by the solution flow, the colored particle-conjugated complexes bind to specific antibodies immobilized in the detection region (Deeks et al., 2020; Ghaffari et al., 2020; Nicol et al., 2020). Although the LFIA is currently the most convenient serological test for SARS-CoV-2, it is prone to give false-negative and false-positive results than other methods (La Rosa Fabian and Urquizo Briceno, 2020; Montesinos et al., 2020). Hu et al. found that EDTA-K2 could chelate with colloidal gold, and the chelated colloidal gold was adsorbed on a conjugate release pad, which significantly improved the sensitivity and specificity of the diagnosis ( $\mathrm{Hu}$ et al., 2021). Stieber et al. reported an LFIA detection device using fluorescent nanoparticles as a signal for antibodies against SARSCoV-2, showing $100 \%$ specificity and sensitivity by qualitative detection of the IgM, IgA, and IgG antibodies against SARS-CoV2 (Stieber et al., 2020). The results of this study need further independent evaluation, but if more researchers can continue to improve the detection accuracy of the LFIA, this method will display greater commercial application value.

\section{Immunofluorescence Assay}

The IFA and ELISA have similar detection strategies, except that the results of the IFA test are shown by fluorescence microscopy. The basic detection process of IFA is to fix SARSCoV-2-infected animal cells (such as Vero cells) on the glass slide, incubated with the patient's serum. After adding fluorescent protein-labeled goat anti-human secondary antibodies, results can be obtained under the fluorescence microscope (Kohmer et al., 2020). This process requires live SARS-CoV-2 virus in the cells, increasing the potential risk of infection. Moreover, the IFA method requires people to observe the fluorescence intensity of cells under microscopy, making the results subjective to a certain extent (Haveri et al., 2020; Goudouris, 2021). The IFA test is also more complicated, subjective, and time-consuming (Venter and Richter, 2020). Due to these disadvantages, the 


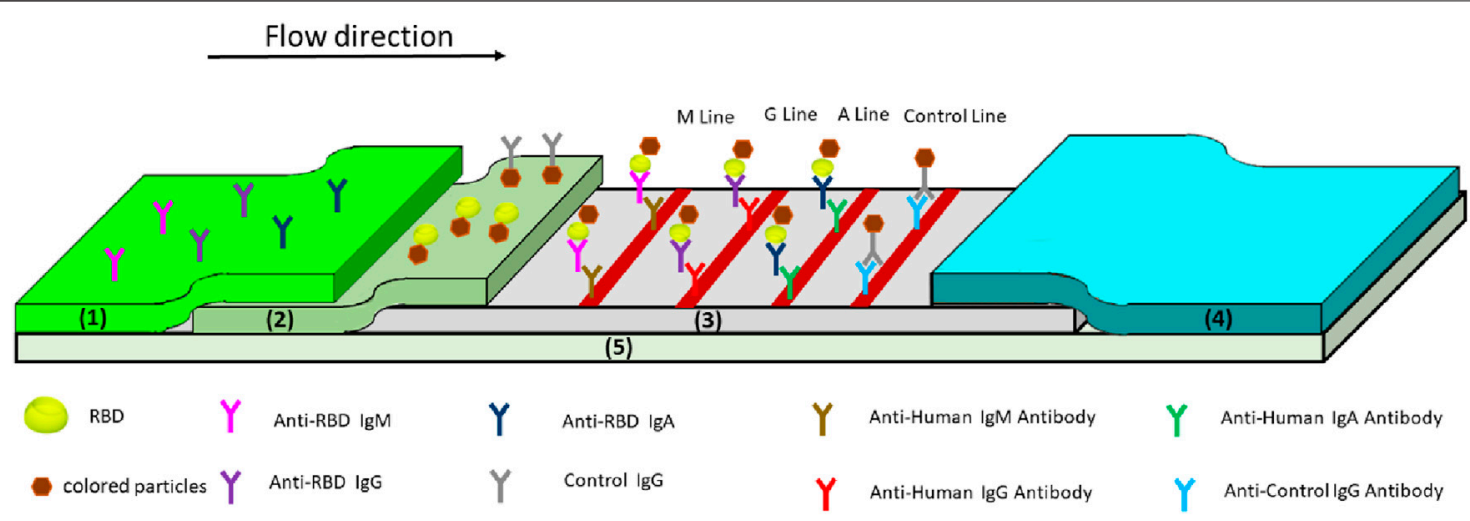

FIGURE 1 | Schematic of the lateral flow immunoassay for testing anti-SARS-COV-2 antibodies (Li, Yi et al., 2020). (1) Sample pad, (2) conjugate release pad, (3) membrane with immobilized antibodies, (4) adsorbent pad, and (5) adhesive pad.

IFA test has not been widely used in the serological diagnosis of SARS-CoV-2 infection.

\section{PERFORMANCE OF SEROLOGICAL TESTS}

With the increasing severity of the COVID-19 epidemic, the need for the development of serological diagnostic technology has become more and more urgent. Governments all over the world are eagerly supporting the development and commercialization of serological tests for SARS-CoV-2. Since the beginning of 2020, a large number of serological tests and kits for SARS-CoV-2 from a variety of institutions have been reported. Because of this, an independent and objective evaluation of various COVID-19 serological tests is needed to ensure the effectiveness of these tests and provide some information for future studies. Sensitivity and specificity are two basic quantitative criteria for evaluating diagnostic methods (Mandrekar, 2010). Sensitivity refers to the ability of these tests to identify positive samples. The higher the sensitivity, the fewer the false-negative results. Specificity is the ability of these tests to identify negative samples, and the higher the specificity, the fewer the false-negative results (Li et al., 2020; Goudouris, 2021).

Over the past year, there have been an increasing number of independent studies on serological tests for SARS-CoV-2, mainly involving performance evaluation and improvement of testing methods. We reviewed as many relevant studies as possible and systematically analyzed their data. As shown in Table 1, we collected 68 test results, including 32 ELISA tests, 15 CLIA tests, 18 LFIA tests, and 3 IFA tests (some of them from the same study). The tests were classified by different methods: ELISA, LFIA, CLIA, or IFA. We carefully summarized sensitivity and specificity for antigen (N, S, S1, and RBD)specific antibodies (IgG, IgM, IgA).

We compared the differences in diagnostic effects of different detection techniques or different detection target antibodies (Figure 2). In a word, the ELISA was less sensitive than the CLIA but more sensitive than the LFIA in COVID-19 diagnosis, meaning that the CLIA test is more effective for the diagnosis of early infected patients with low antibody concentrations. The specificity of the CLIA and LFIA was similar, but the overall specificity of the CLIA was slightly higher than that of the other two tests (Figure 2B). Thus, the CLIA performed best overall in COVID-19 diagnosis, while the LFIA technology increased its accuracy. In addition, comparing the results of different targeted antibodies, we found the combination of IgM and IgG detection could significantly improve the sensitivity of the above three detection methods (Figure 2A). Moreover, the sensitivity and specificity of the ELISA for IgA detection are very high, which means that IgA may be widely used as an important indicator. The number of IFA tests was too small for statistical analysis. Besides, we compared the merits and drawbacks of COVID-19 serological diagnosis methods according to several evaluation criteria including sensitivity, specificity, cost, simplicity, and security (Table 2).

\section{DISCUSSION}

COVID-19 has now become the most prevalent and widespread plague in the global human society. Due to the inability of most countries to control COVID-19, it is likely to continue to rage for a long time, and both developed and undeveloped countries are scrambling to stockpile vaccines. SARS-CoV-2 has been reported in multiple countries with different mutations, which increased infectiousness and resistance, resulting in cross-infection of different SARS-CoV-2 mutant strains in some patients (Gong et al., 2020; Sun et al., 2020; Leung et al., 2021). It is difficult to ensure the existing vaccines remain effective against reported or unknown mutant strains (Veljkovic et al., 2020; Lauring and Hodcroft, 2021; Veljkovic et al., 2021). In addition, virus antibody dynamics studies have shown that serum SARS-CoV-2-specific antibodies levels would rapidly drop $50 \%$ in $5^{\circ}$ months after infection (Conte, 2020; Du et al., 2020; Woo et al., 2004). Based on the fact that SARS-CoV-1 patients' IgG can last $8-24^{\circ}$ months after the onset of symptoms, the COVID-19 patients may encounter the secondary infection when their 
TABLE 1 | Summary of previous studies on sensitivity and specificity of COVID-19 serological diagnosis.

\begin{tabular}{|c|c|c|c|c|c|c|c|c|c|}
\hline \multirow[t]{2}{*}{ Methods and studies } & \multirow[t]{2}{*}{ Antigens } & \multicolumn{2}{|c|}{$\lg M$} & \multicolumn{2}{|c|}{$\lg G$} & \multicolumn{2}{|c|}{$\lg M$ or $\lg G$} & \multicolumn{2}{|c|}{$\lg A$} \\
\hline & & $\begin{array}{c}\text { Sensitivity } \\
(\%)\end{array}$ & $\begin{array}{c}\text { Specificity } \\
\text { (\%) }\end{array}$ & $\begin{array}{c}\text { Sensitivity } \\
(\%)\end{array}$ & $\begin{array}{c}\text { Specificity } \\
\text { (\%) }\end{array}$ & $\begin{array}{c}\text { Sensitivity } \\
(\%)\end{array}$ & $\begin{array}{c}\text { Specificity } \\
(\%)\end{array}$ & $\begin{array}{c}\text { Sensitivity } \\
\text { (\%) }\end{array}$ & $\begin{array}{c}\text { Specificity } \\
(\%)\end{array}$ \\
\hline \multicolumn{10}{|l|}{ ELISA } \\
\hline $\begin{array}{l}\text { Lassaunière et al. } \\
\text { (2020) }\end{array}$ & S & & & 65.0 & 96.0 & & & 90.0 & 93.0 \\
\hline Guo et al. (2020) & $\mathrm{N}$ & 85.4 & & 77.9 & & & & 92.7 & \\
\hline Dogan et al. (2020) & $\mathrm{N}$ & & & 99.1 & 94.9 & & & & \\
\hline & RBD & 100 & 90.9 & 100 & 99.3 & & & 94.3 & 87.9 \\
\hline Snoeck et al. (2020) & $\begin{array}{l}\text { SARS- } \\
\text { CoV-2 }\end{array}$ & & & 97.8 & 85.7 & & & 89.2 & 92.9 \\
\hline $\begin{array}{l}\text { Varadhachary et al. } \\
\text { (2020) } \\
\text { Bailey et al. (2020) }\end{array}$ & $\mathrm{N}, \mathrm{S} 1$ & & & & & & & 92.0 & 97.0 \\
\hline Kit 1 & $\mathrm{~N}$ & & & 100 & 99.6 & & & & \\
\hline Kit 2 & S1 & & & 99.4 & 99.6 & & & & \\
\hline Kit 3 & $S$ & & & 97.6 & 99.3 & & & & \\
\hline Kit 4 & S1 & & & 94.4 & 99.6 & & & & \\
\hline Kit 5 & S1 & & & & & & & 100 & 92.5 \\
\hline Kit 6 & S & & & 85.7 & 100 & & & & \\
\hline Bortz et al. (2020) & $S$ & & & 91.0 & 99.0 & & & 70.0 & 99.0 \\
\hline lyer et al. (2020) & $S$ & 81.0 & 100 & 97.0 & 100 & & & 91.0 & 100 \\
\hline \multicolumn{10}{|l|}{$\begin{array}{l}\text { GeurtsvanKessel et al. } \\
\text { (2020) }\end{array}$} \\
\hline Kit 1 & RBD & 99.0 & 90.0 & 99.0 & 81.0 & & & 94.0 & 97.0 \\
\hline Kit 2 & S1 & & & & & & & & \\
\hline $\begin{array}{l}\text { Kit } 3 \\
\text { Fujigaki et al. (2020) }\end{array}$ & S1 & & & & & & & & \\
\hline Kit 1 & RBD & 79.7 & 94.0 & 77.9 & 98.0 & & & 80.2 & 97.0 \\
\hline Kit 2 & S1 & 76.8 & 99.0 & 72.1 & 97.0 & & & 79.1 & 94.0 \\
\hline Kit 3 & $\mathrm{~N}$ & 63.8 & 88.0 & 84.3 & 79.0 & & & 80.2 & 82.0 \\
\hline La Rosa Fabian and & $S$ & & & & & & & 92.3 & 65.4 \\
\hline \multicolumn{10}{|l|}{ Urquizo Briceno (2020) } \\
\hline Huynh et al. (2020) & $S$ & 100 & 95.5 & 100 & 96.7 & & & 100 & 97.6 \\
\hline & RBD & 100 & 97.3 & 100 & 94.6 & & & 100 & 97.0 \\
\hline $\begin{array}{l}\text { Tre-Hardy et al. (2021) } \\
\text { Nuccetelli et al. (2020) }\end{array}$ & $\mathrm{N}$ & 48.7 & 98.7 & 94.9 & 96.2 & & & 89.7 & 98.7 \\
\hline Kit 1 & $\mathrm{~N}$ & 80.0 & 100 & 94.0 & 93.0 & & & 82.0 & 93.0 \\
\hline Kit 2 & $\mathrm{~N}$ & 92.0 & 100 & 98.0 & 94.0 & & & 92.0 & 94.0 \\
\hline \multicolumn{10}{|l|}{$\begin{array}{l}\text { Van Elslande et al. } \\
(2020)\end{array}$} \\
\hline Kit 1 & S & 39.2 & 91.3 & 62.1 & 98.1 & 65.4 & 90.3 & & \\
\hline Kit 2 & $S$ & 72.5 & 95.1 & 68.0 & 93.2 & 76.5 & 91.3 & & \\
\hline Kit 3 & $S$ & 65.4 & 100 & 62.8 & 99.0 & 65.4 & 99.0 & & \\
\hline Kit 4 & $S$ & 32.0 & 99.0 & 64.7 & 99.0 & 66.7 & 98.1 & & \\
\hline Kit 5 & $\mathrm{~N}$ & 69.3 & 95.1 & 61.4 & 99.0 & 69.3 & 95.2 & & \\
\hline Kit 6 & $\mathrm{~N}$ & 43.8 & 91.3 & 64.7 & 97.2 & 71.2 & 88.3 & & \\
\hline Kit 7 & $\mathrm{~N}$ & 56.2 & 93.2 & 71.2 & 90.3 & 79.1 & 85.4 & & \\
\hline $\begin{array}{l}\text { Jaaskelainen et al. } \\
\text { (2020) }\end{array}$ & $\mathrm{S} 1$ & & & 33.3 & 91.9 & & & 61.5 & 73.0 \\
\hline Beavis et al. (2020) & $\mathrm{S} 1$ & & & 82.9 & 88.4 & & & 67.1 & 97.1 \\
\hline $\begin{array}{l}\text { Sterlin et al. (2020) } \\
\text { Pieri et al. (2020) }\end{array}$ & $S$ & & & & & 91.0 & 98.0 & & \\
\hline Kit 1 & $\mathrm{~N}$ & & & 33.3-80.0 & 98.5 & & & $50.0-100$ & 92.5 \\
\hline Kit 2 & $\mathrm{~N}$ & 88.2 & 92.0 & 92.5 & 93.3 & & & & \\
\hline \multirow{2}{*}{$\begin{array}{l}\text { Liu, Liu, Kou et al. } \\
\text { (2020) }\end{array}$} & $N$ & 68.2 & 100 & 70.1 & 100 & 80.4 & 100 & & \\
\hline & $S$ & 77.1 & 100 & 74.3 & 100 & 82.2 & 100 & & \\
\hline Adams et al. (2020) & $S$ & 70.0 & 100 & 85.0 & 100 & 85.0 & 100 & & \\
\hline Whitman et al. (2020) & $S$ & 56.9 & 96.9 & 73.8 & 88.8 & 75.4 & 87.5 & & \\
\hline & $\mathrm{N}$ & & & & & 72.3 & 95.0 & & \\
\hline $\begin{array}{l}\text { Liu, Liu, Zheng et al. } \\
\text { (2020) }\end{array}$ & $\mathrm{N}$ & & & & & 83.0 & 96.6 & & \\
\hline Freeman et al. (2020) & $S$ & & & & & 96.0 & 99.3 & & \\
\hline
\end{tabular}


TABLE 1 | (Continued) Summary of previous studies on sensitivity and specificity of COVID-19 serological diagnosis.

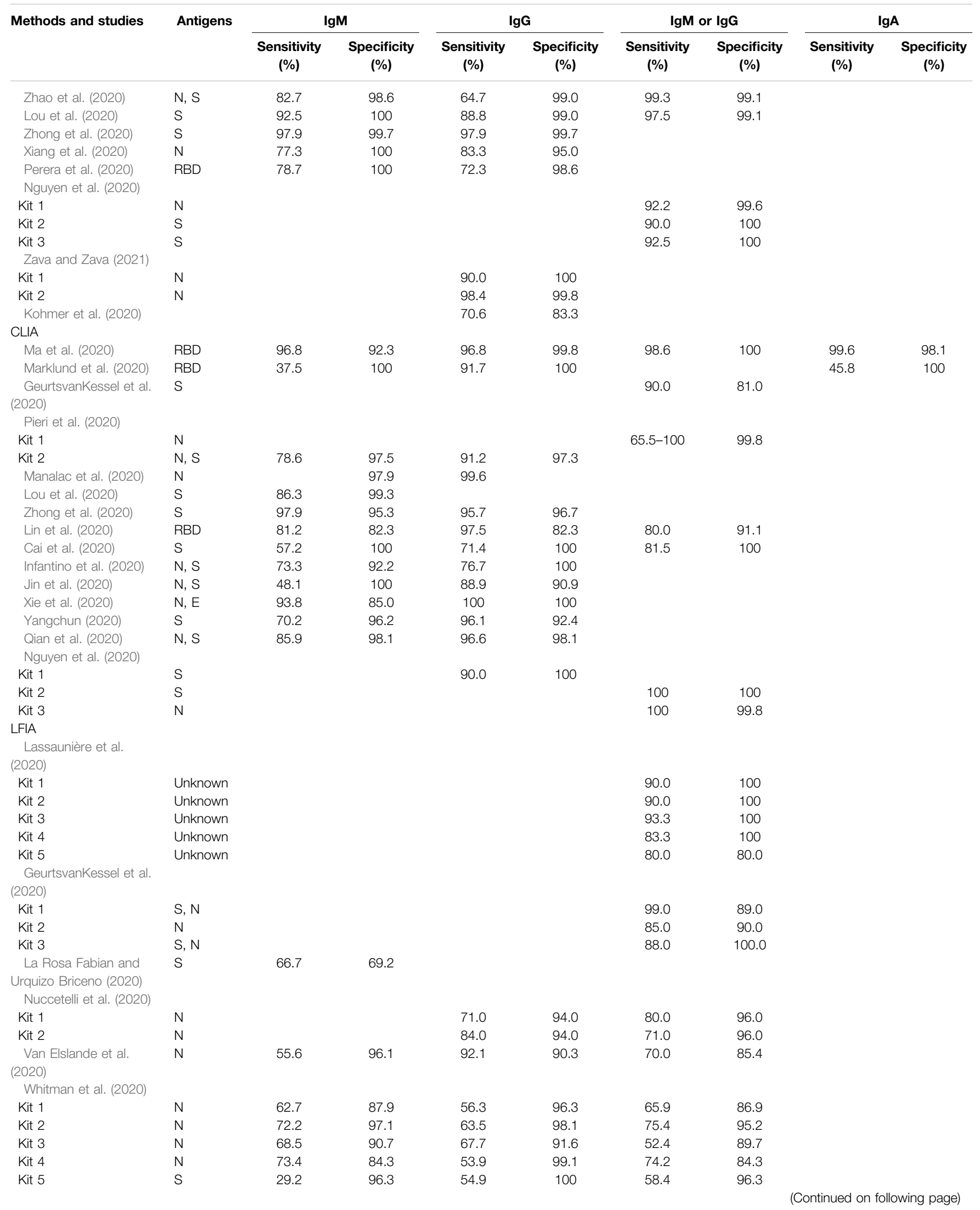


TABLE 1 | (Continued) Summary of previous studies on sensitivity and specificity of COVID-19 serological diagnosis.

\begin{tabular}{|c|c|c|c|c|c|c|c|c|c|}
\hline \multirow[t]{2}{*}{ Methods and studies } & \multirow[t]{2}{*}{ Antigens } & \multicolumn{2}{|c|}{$\lg M$} & \multicolumn{2}{|c|}{$\lg G$} & \multicolumn{2}{|c|}{$\lg M$ or $\lg G$} & \multicolumn{2}{|c|}{$\operatorname{Ig} A$} \\
\hline & & $\begin{array}{c}\text { Sensitivity } \\
(\%)\end{array}$ & $\begin{array}{c}\text { Specificity } \\
(\%)\end{array}$ & $\begin{array}{c}\text { Sensitivity } \\
(\%)\end{array}$ & $\begin{array}{c}\text { Specificity } \\
(\%)\end{array}$ & $\begin{array}{c}\text { Sensitivity } \\
(\%)\end{array}$ & $\begin{array}{c}\text { Specificity } \\
(\%)\end{array}$ & $\begin{array}{c}\text { Sensitivity } \\
(\%)\end{array}$ & $\begin{array}{c}\text { Specificity } \\
(\%)\end{array}$ \\
\hline Kit 6 & $S$ & 70.1 & 98.1 & 54.3 & 99.1 & 71.7 & 97.2 & & \\
\hline Kit 7 & $S$ & 48.8 & 100 & 57.5 & 100 & 50.4 & 100 & & \\
\hline Kit 8 & $S$ & 57.8 & 98.1 & 57.0 & 98.1 & 46.9 & 98.1 & & \\
\hline Kit 9 & $S$ & 66.4 & 94.9 & 64.7 & 96.0 & 66.4 & 94.9 & & \\
\hline Kit 10 & $\mathrm{~N}$ & & & & & 70.2 & 99.1 & & \\
\hline Lou et al. (2020) & $S$ & 88.8 & 98.1 & 86.3 & 99.5 & 97.5 & 95.2 & & \\
\hline Li et al. (2020) & $S$ & 82.6 & 91.4 & 70.5 & 94.1 & 88.7 & 90.6 & & \\
\hline $\begin{array}{l}\text { Pérez-García et al. } \\
(2020)\end{array}$ & $\mathrm{N}$ & 21.8 & 100 & 41.8 & 100 & 47.3 & 100 & & \\
\hline Imai et al. (2020) & $\mathrm{N}$ & 43.2 & 97.9 & 14.4 & 100 & 43.2 & 97.9 & & \\
\hline Ying et al. (2020) & $S$ & 37.8 & 93.3 & 83.3 & 92.1 & 85.6 & 91.0 & & \\
\hline Cassaniti et al. (2020) & $S$ & 83.3 & 100 & 80.0 & 100 & 83.3 & 100 & & \\
\hline Hoffman et al. (2020) & $N, S$ & 69.0 & 100 & 93.1 & 99.2 & & & & \\
\hline Chen et al. (2020) & $\mathrm{N}, \mathrm{S}$ & & & 100 & 91.7 & & & & \\
\hline Zhang et al. (2020) & RBD & & & & & 86.9 & 99.4 & & \\
\hline $\begin{array}{l}\text { VirgilioParadiso et al. } \\
\text { (2020a) } \\
\text { Nguyen et al. (2020) }\end{array}$ & $\mathrm{RBD}$ & & & & & 30.7 & 89.2 & & \\
\hline Kit 1 & $S$ & 95.7 & 99.7 & 99.0 & 99.4 & 99.0 & 99.0 & & \\
\hline Kit 2 & $S$ & & & & & 93.8 & 96.0 & & \\
\hline $\begin{array}{l}\text { Kit } 3 \\
\text { Kohmer et al. (2020) }\end{array}$ & $\mathrm{N}$ & 77.4 & & $\begin{array}{l}87.1 \\
62.5\end{array}$ & 100 & 93.5 & 94.4 & & \\
\hline IFA & & & & & & & & & \\
\hline $\begin{array}{l}\text { Jia (VirgilioParadiso } \\
\text { et. al., 2020b) }\end{array}$ & & 72.0 & 39.0 & 71.0 & 52.0 & 87.5 & 72.7 & & \\
\hline Kohmer et al. (2020) & & & & 76.5 & 86.4 & & & & \\
\hline Edouard et al. (2021) & & & & 41.0 & 93.0 & & & & \\
\hline
\end{tabular}
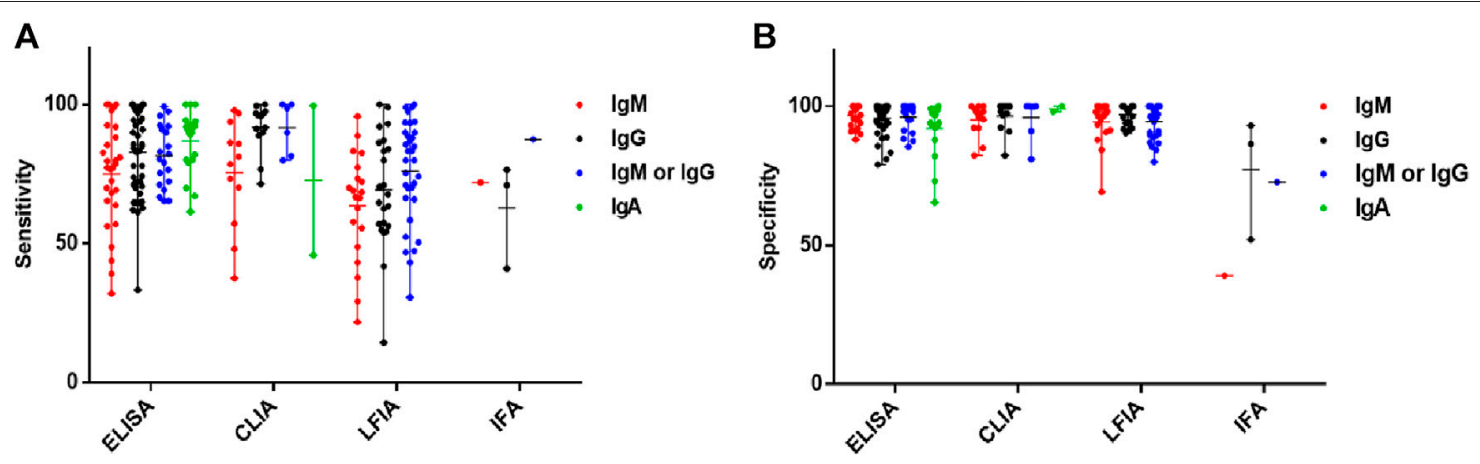

FIGURE 2 | Effectiveness of different serological diagnosis tests for anti-SARS-COV-2 antibodies. Sensitivity (A) and specificity (B) of ELISA, CLIA, LFIA, and IFA tests for anti-SARS-COV-2 IgM, IgG, and $\lg A$.

TABLE 2 | Comparison and evaluation of COVID-19 serological diagnosis methods.

\begin{tabular}{lllll}
\hline & \multicolumn{1}{c}{ ELISA } & \multicolumn{1}{c}{ CLIA } & \multicolumn{1}{c}{ LFIA } & \multicolumn{1}{c}{ IFA } \\
\hline Sensitivity & Medium & High & Low & Medium \\
Specificity & Medium & High & Medium & Low \\
Cost & Medium & High & Low & Medium \\
Simplicity & Medium & Relatively simple & Simple & Complicated \\
Convenience & Lab/hospital & Lab/hospital & Portable & Lab \\
Security & Relatively safe & Safe & Safe & Dangerous
\end{tabular}

antibodies disappear (Liu et al., 2006; Woo et al., 2004; Wu et al., 2007).

These discouraging findings suggest that SARS-CoV-2 may not be eliminated altogether but instead become a seasonal virus, like the flu virus (Neher et al., 2020; Poole, 2020). Therefore, the development and popularization of various COVID-19 diagnostic technologies are needed for controlling the epidemic. There are two main diagnostic techniques: molecular tests and serological tests. Initially, most of the attention focused on the SARS-CoV-2 molecular assay, which 
can detect virus-specific RNA molecules circulating in the host with high precision. The gold standard for molecular testing is based on reverse transcription polymerase chain reaction (RTPCR), a routine confirmation test conducted by the World Health Organization (WHO). At an early stage of SARS-CoV-2 infection, the viral load in the human body is considerably high, while the specific antibodies appear several days later and the concentration is low at that time. Therefore, the accuracy of RT-PCR for COVID-19 patients at an early stage of infection is reliable. However, Li et al. reported that the specific antibodies of SARS-CoV-2 could still be detected in the serum of PCR-negative patients. With the initiation of human immune response and the reduction of viral load, the accuracy of nucleic acid detection began to decrease, and the diagnostic validity of serological detection began to exceed that of the nucleic acid assay (Guo et al., 2020). Serological tests can not only replace nucleic acid tests and reduce the proportion of false-negative diagnoses but also help retrospectively assess the incidence and phase of an outbreak in an area.

The development of effective and reliable serological detection methods plays a vital role in monitoring the abundance and neutralization efficiency of antibodies in infected patients, evaluating and predicting the severity of symptoms of patients, and quantifying the quality of immune response to newborn vaccines. In addition, a variety of serological tests are costeffective, convenient, and efficient than RT-PCR detection for commercial application. Here, we reviewed the latest knowledge on the composition and function of SARS-CoV-2 and the humoral immune response it causes, as well as on the current popular serological detection techniques, including the ELISA, CLIA, LFIA, and IFA. We present the fundamentals of these commercial and laboratory-based detection techniques and the advantages and limitations of application in COVID-19 diagnosis. In addition, we summarized published reports that have evaluated various serological tests, analyzing and comparing the effectiveness of these tests in the diagnosis of COVID-19. In terms of serological diagnosis techniques, although the ELISA and CLIA have shown relatively prominent accuracy, they are still limited to laboratories and clinics due to the complex testing process, high cost, and reliance on sophisticated detection instruments. The experimental conditions of the IFA are more hazardous, and the test results are not easy to be quantified. The LFIA test is more prone to give false-positive and false-negative results than other test technologies, but it has the advantages of convenience, simplicity, low cost, and the potential for large-scale screening.

Given our collection of reported studies, the performance of these serological tests varies widely, with some tests falling far short of the sensitivity and effectiveness criteria proposed by the

\section{REFERENCES}

Adams, E. R., Ainsworth, M., Anand, R., Andersson, M. I., Auckland, K., Baillie, J. K., et al. (2020). Antibody Testing for COVID-19: A Report from the National COVID Scientific Advisory Panel. medRxiv. doi:10.1101/ 2020.04.15.20066407
FDA. In particular, some serological tests showed the sensitivity at an early stage of infection is much lower than that at a late stage of infection. Moreover, the sensitivity can approach $90 \%$ only for patients who have been infected more than $15^{\circ}$ days, implying that enhanced diagnosis accuracy is still necessary (Fujigaki et al., 2020; Wolf et al., 2020). Already, some commercial tests on the market have been recalled due to substandard performance. At the same time, among these different serological detection techniques, a considerable number of studies have reported good detection effects. Due to the limitations of the researchers' environment and scientific study conditions, these independent investigations typically detected just $10-50$ patient samples, which is insufficient for validation. Therefore, good performance based on a large number of samples will contribute to the development and improvement of serological test technology.

\section{CONCLUDING REMARKS}

In this review, we discussed the most prevalent serological diagnostic approaches for SARS-CoV-2-specific antibodies, compared their merits and drawbacks, and evaluated their efficacy in diagnosing COVID-19. The potential and significance of serological tests in the diagnosis of COVID-19 are widely understood. More and more serological test technologies and commercial serological tests are being developed. Although the results of serological tests vary greatly, some of them display excellent performance. With technological innovation and rigorous regulatory evaluation, the accuracy and effectiveness of serological tests will continue to help prevent the SARS-CoV-2 infection.

\section{AUTHOR CONTRIBUTIONS}

BL and LL planned the overall structure of the review. FG and HW wrote the manuscript. QL prepared the figures. All authors contributed to the article and approved the submitted version.

\section{FUNDING}

This work was supported by the National Natural Science Foundation of China (Grant No. 81974258), the COVID-19 special task grant from Chinese Academy of Sciences Clinical Research Hospital (Hefei) (YD9110002006), and the Fundamental Research Funds for the Central Universities (WK9110000092).

Anfossi, L., Di Nardo, F., Cavalera, S., Giovannoli, C., and Baggiani, C. (2018) Multiplex Lateral Flow Immunoassay: An Overview of Strategies towards HighThroughput Point-of-Need Testing. Biosensors (Basel) 9. 2. doi:10.3390/ bios9010002

Ang, S. H., Rambeli, M., Thevarajah, T. M., Alias, Y. B., and Khor, S. M. (2016). Quantitative, Single-step Dual Measurement of Hemoglobin A1c and Total Hemoglobin in Human Whole Blood Using a Gold sandwich 
Immunochromatographic Assay for Personalized Medicine. Biosens. Bioelectron. 78, 187-193. doi:10.1016/j.bios.2015.11.045

Asselah, T., Durantel, D., Pasmant, E., Lau, G., and Schinazi, R. F. (2021). COVID19: Discovery, Diagnostics and Drug Development. J. Hepatol. 74, 168-184. doi:10.1016/j.jhep.2020.09.031

Bailey, D., Konforte, D., Barakauskas, V. E., Yip, P. M., Kulasingam, V., Abou El Hassan, M., et al. (2020). Canadian Society of Clinical Chemists (CSCC) Interim Consensus Guidance for Testing and Reporting of SARS-CoV-2 Serology. Clin. Biochem. 86, 1-7. doi:10.1016/j.clinbiochem.2020.09.005

Basavaraju, S. V., Patton, M. E., Grimm, K., Rasheed, M. A. U., Lester, S., Mills, L., et al. (2020). Serologic Testing of U.S. Blood Donations to Identify SARS-CoV2-Reactive Antibodies: December 2019-January 2020. Clin. Infect. Dis. 72, e1004. doi:10.1093/cid/ciaal785

Beavis, K. G., Matushek, S. M., Abeleda, A. P. F., Bethel, C., Hunt, C., Gillen, S., et al. (2020). Evaluation of the EUROIMMUN Anti-SARS-CoV-2 ELISA Assay for Detection of IgA and IgG Antibodies. J. Clin. Virol. 129, 104468. doi:10.1016/ j.jcv.2020.104468

Berlin, D. A., Gulick, R. M., and Martinez, F. J. (2020). Severe Covid-19. N. Engl. J. Med. 383, 2451-2460. doi:10.1056/NEJMcp2009575

Bever, C. S., Adams, C. A., Hnasko, R. M., Cheng, L. W., and Stanker, L. H. (2020). Lateral Flow Immunoassay (LFIA) for the Detection of Lethal Amatoxins from Mushrooms. PLoS One 15, e0231781. doi:10.1371/journal.pone.0231781

Bortz, R. H., Florez, C., Laudermilch, E., Wirchnianski, A. S., Lasso, G., Malonis, R. J., et al. (2020). Development, Clinical Translation, and Utility of a COVID-19 Antibody Test with Qualitative and Quantitative Readouts. medRxiv. doi:10.1101/2020.09.10.20192187

Butler, J. E. (2000). Enzyme-linked Immunosorbent Assay. J. Immunoassay. 21, 165-209. doi:10.1080/01971520009349533

Cai, X.-f., Chen, J., Hu, J.-l., Long, Q.-x., Deng, H.-j., Fan, K., et al. (2020). A Peptide-Based Magnetic Chemiluminescence Enzyme Immunoassay for Serological Diagnosis of (COVID-19). medRxiv. doi:10.1101/ 2020.02.22.20026617

Carrio, A., Sampedro, C., Sanchez-Lopez, J. L., Pimienta, M., and Campoy, P. (2015). Automated Low-Cost Smartphone-Based Lateral Flow Saliva Test Reader for Drugs-Of-Abuse Detection. Sensors (Basel) 15, 29569-29593. doi:10.3390/s151129569

Cassaniti, I., Novazzi, F., Giardina, F., Salinaro, F., Sachs, M., Perlini, S., et al. (2020). Performance of VivaDiag COVID-19 IgM/IgG Rapid Test Is Inadequate for Diagnosis of COVID-19 in Acute Patients Referring to Emergency Room Department. J. Med. Virol. 92, 1724-1727. doi:10.1002/ jmv. 25800

Chen, Z., Zhang, Z., Zhai, X., Li, Y., Lin, L., Zhao, H., et al. (2020). Rapid and Sensitive Detection of Anti-SARS-CoV-2 IgG, Using Lanthanide-Doped Nanoparticles-Based Lateral Flow Immunoassay. Anal. Chem. 92, 7226-7231. doi:10.1021/acs.analchem.0c00784

Combadiere, B. (2020). [Adaptive Immunity against SARS-CoV-2]. Med. Sci. (Paris) 36, 908-913. doi:10.1051/medsci/2020168

Conte, W. L. (2020). Attenuation of Antibody Response to SARS-CoV-2 in a Patient on Ocrelizumab with Hypogammaglobulinemia. Mult. Scler. Relat. Disord. 44, 102315. doi:10.1016/j.msard.2020.102315

Deeks, J. J., Dinnes, J., Takwoingi, Y., Davenport, C., Spijker, R., Taylor-Phillips, S., et al. (2020). Antibody Tests for Identification of Current and Past Infection with SARS-CoV-2. Cochrane Database Syst. Rev. 6, CD013652. doi:10.1002/ 14651858.CD013652

Dogan, M., Kozhaya, L., Placek, L., Gunter, C. L., Yigit, M., Hardy, R., et al. (2020). Novel SARS-CoV-2 Specific Antibody and Neutralization Assays Reveal Wide Range of Humoral Immune Response during COVID-19. medRxiv. doi:10.1101/2020.07.07.20148106

Du, Z., Zhu, F., Guo, F., Yang, B., and Wang, T. (2020). Detection of Antibodies against SARS-CoV-2 in Patients with COVID-19. J. Med. Virol. 92, 1735-1738. doi:10.1002/jmv.25820

Edouard, S., Colson, P., Melenotte, C., Di Pinto, F., Thomas, L., La Scola, B., et al. (2021). Evaluating the Serological Status of COVID-19 Patients Using an Indirect Immunofluorescent Assay. France. Eur. J. Clin. Microbiol. Infect. Dis. 40, 361-371. doi:10.1007/s10096-020-04104-2

Ejazi, S. A., Ghosh, S., and Ali, N. (2021). Antibody Detection Assays for COVID19 Diagnosis: an Early Overview. Immunol. Cel Biol. 99, 21-33. doi:10.1111/ imcb.12397
Ernst, E., Wolfe, P., Stahura, C., and Edwards, K. A. (2021). Technical Considerations to Development of Serological Tests for SARS-CoV-2. Talanta 224, 121883. doi:10.1016/j.talanta.2020.121883

Espejo, A. P., Akgun, Y., Al Mana, A. F., Tjendra, Y., Millan, N. C., GomezFernandez, C., et al. (2020). Review of Current Advances in Serologic Testing for COVID-19. Am. J. Clin. Pathol. 154, 293-304. doi:10.1093/ajcp/aqaal12

Freeman, B., Lester, S., Mills, L., Rasheed, M. A. U., Moye, S., Abiona, O., et al. (2020). Validation of a SARS-CoV-2 Spike Protein ELISA for Use in Contact Investigations and Serosurveillance. bioRxiv. doi:10.1101/2020.04.24.057323

Fujigaki, H., Inaba, M., Osawa, M., Moriyama, S., Takahashi, Y., Suzuki, T., et al. (2020). Comparative Analysis of Antigen-specific Anti-SARS-CoV-2 Antibody Isotypes in COVID-19 Patients 1. BioRxiv. doi:10.1101/2020.12.04.407510

Fung, T. S., and Liu, D. X. (2019). Human Coronavirus: Host-Pathogen Interaction. Annu. Rev. Microbiol. 73, 529-557. doi:10.1146/annurev-micro020518-115759

Gandhi, R. T., Lynch, J. B., and Del Rio, C. (2020). Mild or Moderate Covid-19. N. Engl. J. Med. 383, 1757-1766. doi:10.1056/NEJMcp2009249

GeurtsvanKessel, C. H., Okba, N. M. A., Igloi, Z., Bogers, S., Embregts, C. W. E., Laksono, B. M., et al. (2020). An Evaluation of COVID-19 Serological Assays Informs Future Diagnostics and Exposure Assessment. Nat. Commun. 11, 3436. doi:10.1038/s41467-020-17317-y

Ghaffari, A., Meurant, R., and Ardakani, A. (2020). COVID-19 Serological Tests: How Well Do They Actually Perform? Diagnostics (Basel) 10. 453. doi:10.3390/ diagnostics 10070453

Gong, Y. N., Tsao, K. C., Hsiao, M. J., Huang, C. G., Huang, P. N., Huang, P. W., et al. (2020). SARS-CoV-2 Genomic Surveillance in Taiwan Revealed Novel ORF8-Deletion Mutant and Clade Possibly Associated with Infections in Middle East. Emerg. Microbes Infect. 9, 1457-1466. doi:10.1080/ 22221751.2020 .1782271

Goudouris, E. S. (2021). Laboratory Diagnosis of COVID-19. J. Pediatr. (Rio J. 97, 7-12. doi:10.1016/j.jped.2020.08.001

Guo, L., Ren, L., Yang, S., Xiao, M., Chang, F., Fang, Y., et al. (2020). Profiling Early Humoral Response to Diagnose Novel Coronavirus Disease (COVID-19). Clin. Infect. Dis. 71, 778-785. doi:10.1093/cid/ciaa310

Haveri, A., Smura, T., Kuivanen, S., Osterlund, P., Hepojoki, J., Ikonen, N., et al. (2020). Serological and Molecular Findings during SARS-CoV-2 Infection: the First Case Study in Finland, January to February 2020. Euro Surveill. 25, 2000266. doi:10.2807/1560-7917.ES.2020.25.11.2000266

Hoffman, T., Nissen, K., Krambrich, J., Ronnberg, B., Akaberi, D., Esmaeilzadeh, M., et al. (2020). Evaluation of a COVID-19 IgM and IgG Rapid Test; an Efficient Tool for Assessment of Past Exposure to SARS-CoV-2. Infect. Ecol. Epidemiol. 10, 1754538. doi:10.1080/20008686.2020.1754538

Hu, X., Wu, C., Situ, B., Tian, P., An, T., Li, Q., et al. (2021). EDTA-K2 Improves the Detection Sensitivity of SARS-CoV-2 IgM and IgG Antibodies by Chelating Colloidal Gold in the Immunochromatographic Assay. Int. J. Nanomedicine 16, 715-724. doi:10.2147/IJN.S281594

Huynh, A., Arnold, D. M., Kelton, J. G., Smith, J. W., Moore, J. C., Chetty, V. T., et al. (2020). Development of a Serological Assay to Identify SARS-CoV-2 Antibodies in COVID-19 Patients. medRxiv. doi:10.1101/2020.09.11.20192690

Imai, K., Tabata, S., Ikeda, M., Noguchi, S., Kitagawa, Y., Matuoka, M., et al. (2020). Clinical Evaluation of an Immunochromatographic IgM/IgG Antibody Assay and Chest Computed Tomography for the Diagnosis of COVID-19. J. Clin. Virol. 128, 104393. doi:10.1016/j.jcv.2020.104393

Infantino, M., Grossi, V., Lari, B., Bambi, R., Perri, A., Manneschi, M., et al. (2020). Diagnostic Accuracy of an Automated Chemiluminescent Immunoassay for Anti-SARS-CoV-2 IgM and IgG Antibodies: an Italian Experience. J. Med. Virol. 92, 1671-1675. doi:10.1002/jmv.25932

Isho, B., Abe, K. T., Zuo, M., Jamal, A. J., Rathod, B., Wang, J. H., et al. (2020). Persistence of Serum and Saliva Antibody Responses to SARS-CoV-2 Spike Antigens in COVID-19 Patients. Sci. Immunol. 5, eabe5511. doi:10.1126/ sciimmunol.abe 5511

Iyer, A. S., Jones, F. K., Nodoushani, A., Kelly, M., Becker, M., Slater, D., et al. (2020). Dynamics and Significance of the Antibody Response to SARS-CoV-2 Infection. medRxiv. doi:10.1101/2020.07.18.20155374

Jaaskelainen, A. J., Kekalainen, E., Kallio-Kokko, H., Mannonen, L., Kortela, E., Vapalahti, O., et al. (2020). Evaluation of Commercial and Automated SARSCoV-2 IgG and IgA ELISAs Using Coronavirus Disease (COVID-19) Patient Samples. Euro Surveill. 25, 200063. doi:10.2807/1560-7917.ES.2020.25.18.2000603 
Jin, Y., Wang, M., Zuo, Z., Fan, C., Ye, F., Cai, Z., et al. (2020). Diagnostic Value and Dynamic Variance of Serum Antibody in Coronavirus Disease 2019. Int. J. Infect. Dis. 94, 49-52. doi:10.1016/j.ijid.2020.03.065

Khan, S., Nakajima, R., Jain, A., de Assis, R. R., Jasinskas, A., Obiero, J. M., et al. (2020). Analysis of Serologic Cross-Reactivity between Common Human Coronaviruses and SARS-CoV-2 Using Coronavirus Antigen Microarray. bioRxiv. doi:10.1101/2020.03.24.006544

Koczula, K. M., and Gallotta, A. (2016). Lateral Flow Assays. Essays Biochem. 60, 111-120. doi:10.1042/EBC20150012

Kohmer, N., Westhaus, S., Rühl, C., Ciesek, S., and Rabenau, H. F. (2020). Clinical Performance of SARS-CoV-2 IgG Antibody Tests and Potential Protective Immunity. bioRxiv. doi:10.1101/2020.05.08.085506

Krishnan, A., Hamilton, J. P., Alqahtani, S. A., and Woreta, T. A. (2021). COVID19: An Overview and a Clinical Update. World J. Clin. Cases 9, 8-23. doi:10.12998/wjcc.v9.i1.8

Krouse, H. J. (2020). COVID-19 and the Widening Gap in Health Inequity. Otolaryngol. Head Neck Surg. 163, 65-66. doi:10.1177/0194599820926463

Kubina, R., and Dziedzic, A. (2020). Molecular and Serological Tests for COVID19 a Comparative Review of SARS-CoV-2 Coronavirus Laboratory and Pointof-Care Diagnostics. Diagnostics (Basel) 10, 434. doi:10.3390/ diagnostics10060434

La Rosa Fabian, C., and Urquizo Briceno, L. (2020). Anti-SARS-Cov-2 IgA in Current Scenario of IgM and IgG Rapid Test: a New Alternative for the Diagnostic of COVID-19. SN Compr. Clin. Med. 2, 2167-2169. doi:10.1007/ s42399-020-00551-2

Lam, S., Singh, R., Dillman, J. R., Trout, A. T., Serai, S. D., Sharma, D., et al. (2020). Antibody Response to SARS-Co-V-2, Diagnostic and Therapeutic Implications. Hepatol. Commun. 4, 1680-1693. doi:10.1002/hep4.1589

Lassaunière, R., Frische, A., Harboe, Z. B., Nielsen, A. C. Y., Fomsgaard, A., Krogfelt, K. A., et al. (2020). Evaluation of Nine Commercial SARS-CoV-2 Immunoassays. MedRxiv. doi:10.1101/2020.04.09.20056325

Lauring, A. S., and Hodcroft, E. B. (2021). Genetic Variants of SARS-CoV-2-What Do They Mean? JAMA 325, 529-531. doi:10.1001/jama.2020.27124

Lequin, R. M. (2005). Enzyme Immunoassay (EIA)/enzyme-linked Immunosorbent Assay (ELISA). Clin. Chem. 51, 2415-2418. doi:10.1373/ clinchem.2005.051532

Leung, K., Shum, M. H., Leung, G. M., Lam, T. T., and Wu, J. T. (2021). Early Transmissibility Assessment of the N501Y Mutant Strains of SARS-CoV-2 in the United Kingdom, October to November 2020. Euro Surveill. 26, 2002106. doi:10.2807/1560-7917.ES.2020.26.1.2002106

Li, C., Zhao, C., Bao, J., Tang, B., Wang, Y., and Gu, B. (2020). Laboratory Diagnosis of Coronavirus Disease-2019 (COVID-19). Clin. Chim. Acta 510, 35-46. doi:10.1016/j.cca.2020.06.045

$\mathrm{Li}, \mathrm{D}$., and Li, J. (2020). Immunologic Testing for SARS-CoV-2 Infection from the Antigen Perspective. J. Clin. Microbiol. 59, e02160. doi:10.1128/JCM.02160-20

Li, Z., Yi, Y., Luo, X., Xiong, N., Liu, Y., Li, S., et al. (2020). Development and Clinical Application of a Rapid IgM-IgG Combined Antibody Test for SARSCoV-2 Infection Diagnosis. J. Med. Virol. 92, 1518-1524. doi:10.1002/ jmv. 25727

Lin, A. V. (2015). Indirect ELISA. Methods Mol. Biol. 1318, 51-59. doi:10.1007/ 978-1-4939-2742-5_5

Lin, D., Liu, L., Zhang, M., Hu, Y., Yang, Q., Guo, J., et al. (2020). Evaluations of the Serological Test in the Diagnosis of 2019 Novel Coronavirus (SARS-CoV-2) Infections during the COVID-19 Outbreak. Eur. J. Clin. Microbiol. Infect. Dis. 39, 2271-2277. doi:10.1007/s10096-020-03978-6

Lin, S. B., Zheng, Z. X., and Zhang, R. (2019). Application and Evaluation of Chemiluminescence Immunoassay in Blood Screening. Zhongguo Shi Yan Xue Ye Xue Za Zhi 27, 569-572. doi:10.19746/j.cnki.issn.1009-2137.2019.02.042

Liu, L., Liu, W., Zheng, Y., Jiang, X., Kou, G., Ding, J., et al. (2020). A Preliminary Study on Serological Assay for Severe Acute Respiratory Syndrome Coronavirus 2 (SARS-CoV-2) in 238 Admitted Hospital Patients. Microbes Infect. 22, 206-211. doi:10.1016/j.micinf.2020.05.008

Liu, W., Fontanet, A., Zhang, P. H., Zhan, L., Xin, Z. T., Baril, L., et al. (2006). Twoyear Prospective Study of the Humoral Immune Response of Patients with Severe Acute Respiratory Syndrome. J. Infect. Dis. 193, 792-795. doi:10.1086/ 500469

Liu, W., Liu, L., Kou, G., Zheng, Y., Ding, Y., Ni, W., et al. (2020). Evaluation of Nucleocapsid and Spike Protein-Based Enzyme-Linked Immunosorbent Assays for Detecting Antibodies against SARS-CoV-2. J. Clin. Microbiol. 58., e00461. doi:10.1128/JCM.00461-20

Long, Q. X., Liu, B. Z., Deng, H. J., Wu, G. C., Deng, K., Chen, Y. K., et al. (2020). Antibody Responses to SARS-CoV-2 in Patients with COVID-19. Nat. Med. 26, 845-848. doi:10.1038/s41591-020-0897-1

Lou, B., Li, T. D., Zheng, S. F., Su, Y. Y., Li, Z. Y., Liu, W., et al. (2020). Serology Characteristics of SARS-CoV-2 Infection after Exposure and post-symptom Onset. Eur. Respir. J. 56, e00763. doi:10.1183/13993003.00763-2020

Ma, H., Zeng, W., He, H., Zhao, D., Jiang, D., Zhou, P., et al. (2020). Serum IgA, IgM, and IgG Responses in COVID-19. Cell Mol Immunol 17, 773-775. doi:10.1038/s41423-020-0474-z

Machado, B. A. S., Hodel, K. V. S., Barbosa-Junior, V. G., Soares, M. B. P., and Badaro, R. (2020). The Main Molecular and Serological Methods for Diagnosing COVID-19: An Overview Based on the Literature. Viruses 13, 40. doi:10.3390/v13010040

Magambo, K. A., Kalluvya, S. E., Kapoor, S. W., Seni, J., Chofle, A. A., Fitzgerald, D. W., et al. (2014). Utility of Urine and Serum Lateral Flow Assays to Determine the Prevalence and Predictors of Cryptococcal Antigenemia in HIV-Positive Outpatients Beginning Antiretroviral Therapy in Mwanza, Tanzania. J. Int. AIDS Soc. 17, 19040. doi:10.7448/IAS.17.1.19040

Mahallawi, W. H. (2021). A Serological Assay to Detect Human SARS-CoV-2 Antibodies. J. Taibah Univ. Med. Sci. 16, 57-62. doi:10.1016/ j.jtumed.2020.11.011

Malik, Y. A. (2020). Properties of Coronavirus and SARS-CoV-2. Malays. J. Pathol. $42,3-11$.

Manalac, J., Yee, J., Calayag, K., Nguyen, L., Patel, P. M., Zhou, D., et al. (2020). Evaluation of Abbott Anti-SARS-CoV-2 CMIA IgG and Euroimmun ELISA IgG/IgA Assays in a Clinical Lab. Clin. Chim. Acta 510, 687-690. doi:10.1016/ j.cca.2020.09.002

Mandrekar, J. N. (2010). Simple Statistical Measures for Diagnostic Accuracy Assessment. J. Thorac. Oncol. 5, 763-764. doi:10.1097/JTO.0b013e3181dab122

Marklund, E., Leach, S., Axelsson, H., Nystrom, K., Norder, H., Bemark, M., et al. (2020). Serum-IgG Responses to SARS-CoV-2 after Mild and Severe COVID19 Infection and Analysis of IgG Non-responders. PLoS One 15, e0241104. doi:10.1371/journal.pone.0241104

Mazzini, L., Martinuzzi, D., Hyseni, I., Benincasa, L., Molesti, E., Casa, E., et al. (2021). Comparative Analyses of SARS-CoV-2 Binding (IgG, IgM, IgA) and Neutralizing Antibodies from Human Serum Samples. J. Immunol. Methods 489, 112937. doi:10.1016/j.jim.2020.112937

Mekonnen, D., Mengist, H. M., Derbie, A., Nibret, E., Munshea, A., He, H., et al. (2020). Diagnostic Accuracy of Serological Tests and Kinetics of Severe Acute Respiratory Syndrome Coronavirus 2 Antibody: A Systematic Review and Meta-Analysis. Rev. Med. Virol. 31, e2181. doi:10.1002/rmv.2181

Montesinos, I., Gruson, D., Kabamba, B., Dahma, H., Van den Wijngaert, S., Reza, S., et al. (2020). Evaluation of Two Automated and Three Rapid Lateral Flow Immunoassays for the Detection of Anti-SARS-CoV-2 Antibodies. J. Clin. Virol. 128, 104413. doi:10.1016/j.jcv.2020.104413

Moreno, M. L., Cebolla, A., Munoz-Suano, A., Carrillo-Carrion, C., Comino, I., Pizarro, A., et al. (2017). Detection of Gluten Immunogenic Peptides in the Urine of Patients with Coeliac Disease Reveals Transgressions in the Glutenfree Diet and Incomplete Mucosal Healing. Gut 66, 250-257. doi:10.1136/ gutjnl-2015-310148

Neher, R. A., Dyrdak, R., Druelle, V., Hodcroft, E. B., and Albert, J. (2020). Potential Impact of Seasonal Forcing on a SARS-CoV-2 Pandemic. Swiss Med. Wkly. 150, w20224. doi:10.4414/smw.2020.20224

Nguyen, N. N. T., McCarthy, C., Lantigua, D., and Camci-Unal, G. (2020). Development of Diagnostic Tests for Detection of SARS-CoV-2. Diagnostics (Basel) 10. doi:10.3390/diagnostics10110905

Nicol, T., Lefeuvre, C., Serri, O., Pivert, A., Joubaud, F., Dubee, V., et al. (2020). Assessment of SARS-CoV-2 Serological Tests for the Diagnosis of COVID-19 through the Evaluation of Three Immunoassays: Two Automated Immunoassays (Euroimmun and Abbott) and One Rapid Lateral Flow Immunoassay (NG Biotech). J. Clin. Virol. 129, 104511. doi:10.1016/ j.jcv.2020.104511

Nuccetelli, M., Pieri, M., Gisone, F., and Bernardini, S. (2020). Combined AntiSARS-CoV-2 IgA, IgG, and IgM Detection as a Better Strategy to Prevent Second Infection Spreading Waves. Immunol. Invest., 1-13. doi:10.1080/ 08820139.2020.1823407 
Okba, N. M. A., Muller, M. A., Li, W., Wang, C., GeurtsvanKessel, C. H., Corman, V. M., et al. (2020). Severe Acute Respiratory Syndrome Coronavirus 2-Specific Antibody Responses in Coronavirus Disease Patients. Emerg. Infect. Dis. 26, 1478-1488. doi:10.3201/eid2607.200841

Padoan, A., Cosma, C., Sciacovelli, L., Faggian, D., and Plebani, M. (2020). Analytical Performances of a Chemiluminescence Immunoassay for SARSCoV-2 IgM/IgG and Antibody Kinetics. Clin. Chem. Lab. Med. 58, 1081-1088. doi:10.1515/cclm-2020-0443

Perera, R. A., Mok, C. K., Tsang, O. T., Lv, H., Ko, R. L., Wu, N. C., et al. (2020). Serological Assays for Severe Acute Respiratory Syndrome Coronavirus 2 (SARS-CoV-2), March 2020. Euro Surveill. 25, 2000421. doi:10.2807/15607917.ES.2020.25.16.2000421

Pérez-García, F., Pérez-Tanoira, R., Romanyk, J., Arroyo, T., Gómez-Herruz, P., and Cuadros-González, J. (2020). Rapid Diagnosis of SARS-CoV-2 Infection by Detecting IgG and IgM Antibodies with an Immunochromatographic Device: a Prospective Single-center Study. medRxiv. doi:10.1101/2020.04.11.20062158

Pieri, M., Ciotti, M., Carlozzi, N., Frassanito, M. L., Meloni, A., Cistera, A., et al. (2020). SARS-CoV-2 Infection Serology Validation of Different Methods: Usefulness of IgA in the Early Phase of Infection. Clin. Chim. Acta 511, 28-32. doi:10.1016/j.cca.2020.09.033

Poole, L. (2020). Seasonal Influences on the Spread of SARS-CoV-2 (COVID19), Causality, and Forecastabililty (3-15-2020). SSRN Electron. J. doi:10.2139/ ssrn. 3554746

Qian, C., Zhou, M., Cheng, F., Lin, X., Gong, Y., Xie, X., et al. (2020). Development and Multicenter Performance Evaluation of the First Fully Automated SARSCoV-2 IgM and IgG Immunoassays. MedRxiv. doi:10.1101/ 2020.04.16.20067231

Reading, S. A., and Dimmock, N. J. (2007). Neutralization of Animal Virus Infectivity by Antibody. Arch. Virol. 152, 1047-1059. doi:10.1007/s00705006-0923-8

Schramm, E. C., Staten, N. R., Zhang, Z., Bruce, S. S., Kellner, C., Atkinson, J. P., et al. (2015). A Quantitative Lateral Flow Assay to Detect Complement Activation in Blood. Anal. Biochem. 477, 78-85. doi:10.1016/j.ab.2015.01.024

Sidiq, Z., Hanif, M., Dwivedi, K. K., and Chopra, K. K. (2020). Benefits and Limitations of Serological Assays in COVID-19 Infection. Indian J. Tuberc. 67, S163-S166. doi:10.1016/j.ijtb.2020.07.034

Snoeck, C. J., Vaillant, M., Abdelrahman, T., Satagopam, V. P., Turner, J. D., Beaumont, K., et al. (2020). Prevalence of SARS-CoV-2 Infection in the Luxembourgish Population - the CON-VINCE Study. MedRxiv. doi:10.1101/2020.05.11.20092916

Sterlin, D., Mathian, A., Miyara, M., Mohr, A., Anna, F., Claer, L., et al. (2020). IgA Dominates the Early Neutralizing Antibody Response to SARS-CoV-2. Sci. Transl. Med. 13, eabd222. doi:10.1126/scitranslmed.abd2223

Stieber, F., Howard, J., Rao, S. N., Kawamura, L. M., Manissero, D., Love, J., et al. (2020). First Performance Report of QIAreach Anti-SARS-CoV-2 Total Test, an Innovative Nanoparticle Fluorescence Digital Detection Platform. J. Clin. Virol. 133, 104681. doi:10.1016/j.jcv.2020.104681

Su, Y. Y., Zhang, S. Y., Li, T. D., and Xia, N. S. (2020). Early Diagnosis and Population Prevention of Coronavirus Disease 2019. Curr. Opin. HIV AIDS 15, 345-350. doi:10.1097/COH.0000000000000649

Sun, Y. S., Xu, F., An, Q., Chen, C., Yang, Z. N., Lu, H. J., et al. (2020). A SARSCoV-2 Variant with the 12-bp Deletion at E Gene. Emerg. Microbes Infect. 9, 2361-2367. doi:10.1080/22221751.2020.1837017

Tan, Y., Pang, W., Jia, X., and Zhao, M. H. (2020). Comparison of the Performance of a Chemiluminescence Assay and an ELISA for Detection of Anti-GBM Antibodies. Ren. Fail. 42, 48-53. doi:10.1080/0886022X.2019.1702056

The Lancet (2020). COVID-19: Too Little, Too Late? The Lancet 395. doi:10.1016/ s0140-6736(20)30522-5

Tre-Hardy, M., Wilmet, A., Beukinga, I., Favresse, J., Dogne, J. M., Douxfils, J., et al. (2021). Analytical and Clinical Validation of an ELISA for Specific SARS-CoV2 IgG, IgA, and IgM Antibodies. J. Med. Virol. 93, 803-811. doi:10.1002/ jmv. 26303

Van Elslande, J., Houben, E., Depypere, M., Brackenier, A., Desmet, S., Andre, E., et al. (2020). Diagnostic Performance of Seven Rapid IgG/IgM Antibody Tests and the Euroimmun IgA/IgG ELISA in COVID-19 Patients. Clin. Microbiol. Infect. 26, 1082-1087. doi:10.1016/j.cmi.2020.05.023

Varadhachary, A., Chatterjee, D., Garza, J., Garr, R. P., Foley, C., Letkeman, A. F., et al. (2020). Salivary Anti-SARS-CoV-2 IgA as an Accessible Biomarker of
Mucosal Immunity against COVID-19. medRxiv. doi:10.1101/ 2020.08.07.20170258

Vashist, S. K. (2020). Vitro Diagnostic Assays for COVID-19: Recent Advances and Emerging Trends, Diagnostics (Basel) 10. doi:10.3390/diagnostics10040202

Veljkovic, V., Perovic, V., Chambers, I., and Paessler, S. (2021). Evolution of SARSCoV-2 Virus and Assessment of the Effectiveness of COVID-19 Vaccine, F1000Research 10. doi:10.12688/f1000research.28215.1

Velikovic, V., Perovic, V., and Paessler, S. (2020). Prediction of the Effectiveness of COVID-19 Vaccine Candidates. F1000Research. 9. doi:10.12688/f1000research.23865.1

Venter, M., and Richter, K. (2020). Towards Effective Diagnostic Assays for COVID19: a Review. J. Clin. Pathol. 73, 370-377. doi:10.1136/jclinpath-2020-206685

VirgilioParadiso, A., De Summa, S., Loconsole, D., Procacci, V., Sallustio, A., Centrone, F., et al. (2020a). Clinical Meanings of Rapid Serological Assay in Patients Tested for SARS-Co2 RT-PCR. MedRxiv. doi:10.1101/2020.04.03.20052183

VirgilioParadiso, A., De Summa, S., Loconsole, D., Procacci, V., Sallustio, A., Centrone, F., et al. (2020b). Clinical Significance of IgM and IgG Test for Diagnosis of Highly Suspected COVID-19 Infection. MedRxiv. doi:10.1101/ 2020.04.03.20052183

Ward, S., Lindsley, A., Courter, J., and Assa'ad, A. (2020). Clinical Testing for COVID-19. J. Allergy Clin. Immunol. 146, 23-34. doi:10.1016/j.jaci.2020.05.012

Weeks, I., Sturgess, M. L., and Woodhead, J. S. (1986). Chemiluminescence Immunoassay: an Overview. Clin. Sci. (Lond.). 70, 403-408. doi:10.1042/cs0700403

Weiss, S. R., and Leibowitz, J. L. (2011). Coronavirus Pathogenesis. Adv. Virus. Res. 81, 85-164. doi:10.1016/B978-0-12-385885-6.00009-2

Whitman, J. D., Hiatt, J., Mowery, C. T., Shy, B. R., Yu, R., Yamamoto, T. N., et al. (2020). Test Performance Evaluation of SARS-CoV-2 Serological Assays. medRxiv. doi:10.1101/2020.04.25.20074856

Wolf, J., Kaiser, T., Pehnke, S., Nickel, O., Lubbert, C., Kalbitz, S., et al. (2020). Differences of SARS-CoV-2 Serological Test Performance between Hospitalized and Outpatient COVID-19 Cases. Clin. Chim. Acta 511, 352-359. doi:10.1016/j.cca.2020.10.035

Wolfel, R., Corman, V. M., Guggemos, W., Seilmaier, M., Zange, S., Muller, M. A., et al. (2020). Virological Assessment of Hospitalized Patients with COVID2019. Nature 581, 465-469. doi:10.1038/s41586-020-2196-x

Woo, P. C., Lau, S. K., Huang, Y., and Yuen, K. Y. (2009). Coronavirus Diversity, Phylogeny and Interspecies Jumping. Exp. Biol. Med. (Maywood). 234, 1117-1127. doi:10.3181/0903-MR-94

Woo, P. C., Lau, S. K., Wong, B. H., Chan, K. H., Chu, C. M., Tsoi, H. W., et al. (2004). Longitudinal Profile of Immunoglobulin G (IgG), IgM, and IgA Antibodies against the Severe Acute Respiratory Syndrome (SARS) Coronavirus Nucleocapsid Protein in Patients with Pneumonia Due to the SARS Coronavirus. Clin. Diagn. Lab. Immunol. 11, 665-668. doi:10.1128/ CDLI.11.4.665-668.2004

Wu, L. P., Wang, N. C., Chang, Y. H., Tian, X. Y., Na, D. Y., Zhang, L. Y., et al. (2007). Duration of Antibody Responses after Severe Acute Respiratory Syndrome. Emerg. Infect. Dis. 13, 1562-1564. doi:10.3201/eid1310.070576

Xiang, F., Wang, X., He, X., Peng, Z., Yang, B., Zhang, J., et al. (2020). Antibody Detection and Dynamic Characteristics in Patients with Coronavirus Disease 2019. Clin. Infect. Dis. 71, 1930-1934. doi:10.1093/cid/ciaa461

Xie, J., Ding, C., Li, J., Wang, Y., Guo, H., Lu, Z., et al. (2020). Characteristics of Patients with Coronavirus Disease (COVID-19) Confirmed Using an IgM-IgG Antibody Test. J. Med. Virol. 92, 2004-2010. doi:10.1002/jmv.25930

Yangchun, F. (2020). Optimize Clinical Laboratory Diagnosis of COVID-19 from Suspect Cases by Likelihood Ratio of SARS-CoV-2 IgM and IgG Antibody. MedRxiv. doi:10.1101/2020.04.07.20053660

Ying, L., Yue-ping, L., Bo, D., Feifei, R., Yue, W., Jinya, D., et al. (2020). Diagnostic Indexes of a Rapid IgG/IgM Combined Antibody Test for SARS-CoV-2. MedRxiv. doi:10.1101/2020.03.26.20044883

Yu, H. Q., Sun, B. Q., Fang, Z. F., Zhao, J. C., Liu, X. Y., Li, Y. M., et al. (2020). Distinct Features of SARS-CoV-2-specific IgA Response in COVID-19 Patients. Eur. Respir. J. 56, 201526. doi:10.1183/13993003.01526-2020

Zava, T. T., and Zava, D. T. (2021). Validation of Dried Blood Spot Sample Modifications to Two Commercially Available COVID-19 IgG Antibody Immunoassays. Bioanalysis 13, 13-28. doi:10.4155/bio-2020-0289

Zhang, P., Gao, Q., Wang, T., Ke, Y., Mo, F., Jia, R., et al. (2020). Evaluation of Recombinant Nucleocapsid and Spike Proteins for Serological Diagnosis of Novel Coronavirus Disease 2019 (COVID-19). MedRxiv. doi:10.1101/ 2020.03.17.20036954 
Zhang, S., Wang, Z., Chang, R., Wang, H., Xu, C., Yu, X., et al. (2020). COVID-19 Containment: China Provides Important Lessons for Global Response. Front. Med. 14, 215-219. doi:10.1007/s11684-020-0766-9

Zhao, J., Yuan, Q., Wang, H., Liu, W., Liao, X., Su, Y., et al. (2020). Antibody Responses to SARS-CoV-2 in Patients with Novel Coronavirus Disease 2019. Clin. Infect. Dis. 71, 2027-2034. doi:10.1093/cid/ciaa344

Zhong, L., Chuan, J., Gong, B., Shuai, P., Zhou, Y., Zhang, Y., et al. (2020). Detection of Serum IgM and IgG for COVID-19 Diagnosis. Sci. China Life Sci. 63, 777-780. doi:10.1007/s11427-020-1688-9

Conflict of Interest: The authors declare that the research was conducted in the absence of any commercial or financial relationships that could be construed as a potential conflict of interest.
Publisher's Note: All claims expressed in this article are solely those of the authors and do not necessarily represent those of their affiliated organizations, or those of the publisher, the editors and the reviewers. Any product that may be evaluated in this article, or claim that may be made by its manufacturer, is not guaranteed or endorsed by the publisher.

Copyright (c) 2021 Gong, Wei, Li, Liu and Li. This is an open-access article distributed under the terms of the Creative Commons Attribution License (CC $B Y)$. The use, distribution or reproduction in other forums is permitted, provided the original author(s) and the copyright owner(s) are credited and that the original publication in this journal is cited, in accordance with accepted academic practice. No use, distribution or reproduction is permitted which does not comply with these terms. 